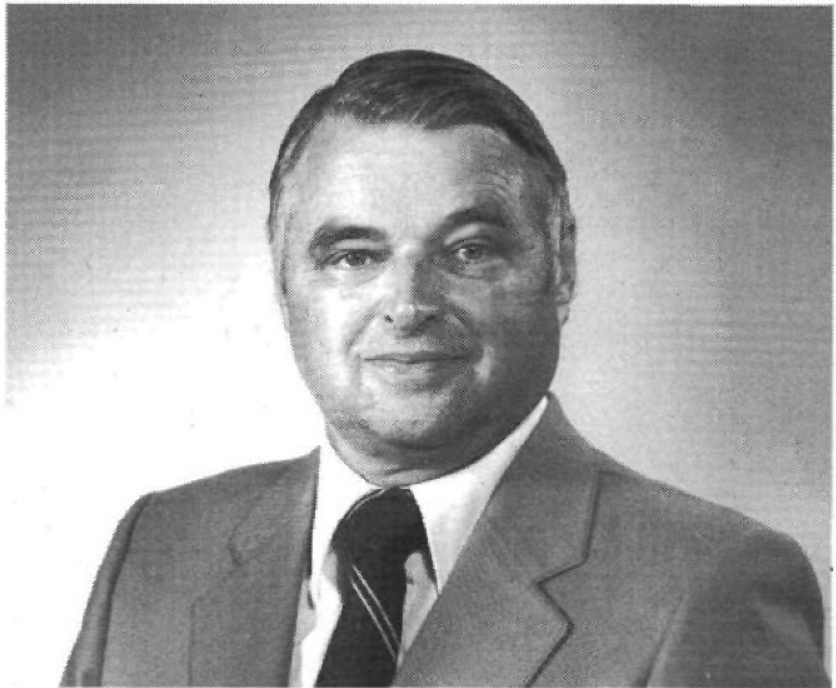

\section{President's Report/Rapport du Président}

In this initial report I would firstly like to indicate that I consider it an honour to be able to serve as your president for the coming year. It is fitting that I assumed this role in Prince George, because that is where I began my forestry career with the Industrial Forestry Service working with the late Larry de Grace who at one time was Vice-President of the CIF/IFC. Secondly, I would be remiss if I did not recognize the contributions made by George Garner, our immediate Past-President and Bruce Devitt, our outgoing member of the Executive Committee. Both of these gentlemen have worked tirelessly for the CIF/IFC and both provided excellent leadership and service. It is also a pleasure to welcome Jim Clark to Executive Committee as Second Vice-President and I am also delighted to report that Bob Bourchier will be our Executive Director commencing January 1983. As many of you know, Bob has worked with the Canadian Forestry Service and the Ontario Ministry of Natural Resources for more than 30 years and brings to the CIF/IFC a wealth of knowledge and experience.

At this time it is traditional that your incoming president outline his plans and priorities for the year ahead. However, the CIF is not a one-man band and as George Garner noted in his President's Report one year ago, plans and priorities are generally of a continuing nature and usually cannot be considered within a one year time frame. With our five-year planning procedures, we have made a good start in defining long-term goals. Nevertheless it does seem appropriate to repeat some of our priorities and to outline some specific goals for this year.

A key goal for last year was to establish the Ottawa office as an efficient service oriented organization. While we can report good progress, we still have some way to move in this connection. I am counting on Doug Redmond, over the next three months, and on Bob Bourchier after that time to continue to make progress in this matter.

Increasing membership is a continuing concern which needs to be seriously addressed. In view of the current economic situation our membership becomes an even greater issue. We must make every attempt to enlist new members and to keep all of our existing members. This will require work on the part of all sections as well was Head Office and each member must do what he can to secure new members. The CIF/IFC needs to expand its program and its services to members, but to do so we need a stronger membership base.

During the coming year our First Vice-President will be continuing with his review of the Working Group structure. While good work has been done by some of the Working Groups, a review has indicated that the current concept is simply not working in a satisfactory manner. We anticipate that a new approach will be developed during this year to ensure that priority technical and scientific issues can be addressed in an efficient manner. In the meantime we intend to finalize statements on the use of pesticides in forestry and on prescribed burning. Other priority issues include education in forestry, the status of forest management in Canada and land alienation from forestry use.

It is our intention to continue to cooperate and communicate with other forestry organizations concerned with promoting improved forest management in Canada. Several initiatives have recently been undertaken in this connection. In Prince George we signed a letter of understanding with the Association of British Columbia Professional Foresters. The memorandum outlines a number of areas of mutual cooperation and is reproduced in this issue. The CIF/IFC has also agreed to participate in a Canadian Federation of Professional Foresters' Association. Member associations are the CIF/IFC and the four provincial forestry associations and the objective is to provide a national voice for professional foresters in Canada. The organization, consisting of one representative of each member association, will meet at least once annually in conjunction with the national annual meeting of the CIF/IFC. Such meetings have actually been held on an informal basis at our last three annual meetings. A third initiative undertaken at Prince George, in cooperation with the Canadian Forestry Association, was to convene a meeting of the Canadian forestry constituency. Attendees included representatives from forest industry associations, labour, four professional forestry associations, two provincial forestry associations and the academic community. A report of this meeting is included in this issue.

1983 marks the 75th anniversary of the CIF/IFC. On March 12, 1908 a small group of foresters met in Montreal and agreed to establish a professional body of foresters. It is our intention to mark the occasion of our 75th anniversary through activities, special coverage in The Forestry Chronicle and at the 1983 Annual Meeting in Sault Ste. Marie which has as its theme "Forestry in Canada - Past, Present and Future". Hugh Peacock, Ottawa Valley, has been appointed our 75 th anniversary coordinator.

I am pleased to be able to report that Don MacKay has now started work on his book on forest management in Canada and that three publishers have expressed interest in publishing the book. Target date for publication is the 1984 Annual Meeting.

It is my belief that we are making progress in improving Canadian forest management. While the recession is having a severe impact we must continue to promote forest management amongst the Canadian public. As professionals we are well aware of the importance of forestry in Canda but many Canadians do not have this awareness. There is no room for complacency and each of you must ask yourself "what can I do for the CIF/IFC and for forestry? It is only through our combined efforts that we can maintain our current momentum.

Jim Cayford 
Nous avons l'intention de continuer à coopérer et à communiquer avec les autres organisations forestières intéressées à la promotion d'un meilleur aménagement des forêts au Canada. Déjà, encore récemment, des démarches ont été entreprises dans ce sens: A Prince George, nous avons signé une lettre d'entente avec l'Association des Forestiers Professionnels de la Colombie Britannique. $\mathrm{Ce}$ mémoire d'entente reproduit plus loin dans ce numéro, prévoit plusieurs sujets de coopération mutuelle.

La CIF/IFC a aussi accepté de participer à une fédération canadienne des associations professionnelles de forestiers dont les membres seront, en plus de l'IFC, les quatre associations provinciales existantes et, dont l'objectif est de fournir, aux forestiers professionnels du Canada, une voix nationale. Le bureau de la fédération, composé d'un représentant de chaque association membre, se réunira au moins une fois l'an lors de l'assemblée annuelle nationale de CIF/IFC. De fait, sur une base informelle, ce genre de rencontre a eu lieu lors de nos trois dernières assemblées annuelles.

Une troisième initiative prise à Prince George, en coopération avec l'Association Forestière du Canada, a été la convocation d'une rencontre de la famille forestière du Canada. Se sont présentés à cette rencontre: des représentants des associations des industries forestières, des unions, des quatre associations professionnelles, de deux associations forestières provinciales et du monde académique. Vous trouverez plus loin dans ce numéro, un rapport de cette rencontre.

1983 marque le $75^{e}$ anniversaire de CIF/IFC. C'est le 12 mars 1908 qu'un petit groupe de forestiers réunis à Montréal décidaient de former une association nationale des forestiers professionnels. C'est par des activités dans les sections, un numéro spécial de "Forestry Chronicle" et lors de l'assembée annuelle de 1983 dont le thème est: "La Foresterie au Canada - son passé, son présent et son futur" ' et qui se tiendra à Sault Ste-Marie, que nous avons l'intention de souligner cet événement. Hugh Peacock, de la section de la Vallée de l'Outaouais, a été nommé coordonnateur de notre $75^{\circ}$ anniversaire.

II me fait également plaisir de rapporter que Don Mackay a commencé son livre sur l'aménagement forestier au Canada et que trois maisons d'édition semblent intéressées à publier ce livre. Nous prévoyons lancer officiellement le livre de Don Mackay lors de l'assemblée annuelle de 1984.

Je crois sincèrement qu'il y a progrès dans notre marche vers une amélioration de l'aménagement des forêts du Canada, mais, malgré que la récession actuelle ait un impact sévère sur l'activité forestière, nous devons persévérer dans nos efforts de promotion de la foresterie auprès du public canadien. Comme professionnels, nous sommes bien au fait de l'importance de la foresterie au Canada mais peu de canadiens en sont conscients. II n'y a plus place pour un "laisser-faire" et chacun de nous doit se demander sérieusement: "qu'est-ce que je puis faire pour l'Institut et pour la Foresterie? Ce n'est que par nos efforts soutenus combinés que nous pourrons maintenir le momemtum actuel.

Jim Cayford

with Best Wishes

for the New year

from

the Editor
CFA-CIF Meeting on Areas for Cooperation and Coordination between Forestry-Oriented Groups

The Presidents of the Canadian Forestry Association and the Canadian Institute of Forestry, K.A. Armson and G.J. Garner, convened a meeting at Prince George on September 29, 1982 to identify common areas for cooperation and coordination between forestry oriented groups. The meeting was held in conjunction with the Annual Meeting of the Canadian Institute of Forestry and was attended by senior representatives of a number of organizations including the Council of Forest Industries of British Columbia, the Canadian Pulp and Paper Association, the International Woodworkers of America, the four Professional Forestry Associations, the Association of University Forestry Schools of Canada, the Canadian Council of Resource and Environment Ministers, the Canadian Forestry Association of British Columbia and the Ontario Forestry Association.

A summary of the meeting follows:

1) There is strong support that a national voice for forestry is required. The objective of such a voice is to improve forest management, renewal and enhancement and to increase public awareness of forestry in Canada. There is a broad constituency that must be marshalled on behalf of forestry.

2) There is strong support for the general concepts of improved communication, coordination and cooperation among forestry groups which must take place at local, provincial and national levels. It is also recognized that no new organizations are required, but that a loose type of coalition or federation of existing organizations may be desirable. Any actions taken on behalf of a national voice will be taken by existing organizations. It was also recognized that there would be no loss of identity of any individual organization and that change must take place in a slow, evolutionary manner.

3) There is general support for a structure which identifies 7 elements within the forestry community. Specific elements include industry, labor, forestry professionals and technicians, the CFA federation, governments, private landowners and academia. In addition, the general public must also be recognized as a user of the forest.

4) Current emphasis is on defining roles and on strenthening the various elements of the forestry constituency. In particular, there are on-going initiatives with respect to industry, labor, the Canadian Forestry Association and forestry professionals. The industrial groups are meeting in November, while a Canadian Federation of Professional Foresters Associations is in the formulative stage, and the Association of University Forestry Schools of Canada has been operational for a number of years.

5) Regardless of the fact that current emphasis is within the specific elements, there are several examples of communication, cooperation, and coordination between organizations within different elements. Some specific examples include the 1977 Forest Regeneration Conference, the 1980 Canadian Forestry Congress, the Banff Congress, the 1982 Saskatchewan Forestry Congress, the proposal by the Canadian Forestry Association of British Columbia for a Public Forest Education Council, the Forestry Forum, and the recent symposium in Vancouver dealing with financing for forest renewal and sponsored by the Association of BC Professional Foresters and the International Woodworkers of America.

6) It was agreed that the CIF-CFA should take the lead in convening the next meeting of representatives of the various elements of the forestry constituency for the purpose of idenfifying action programs related to the objectives of the forestry constituency.

J.H. Cayford October 22, 1982 


\section{LETTER OF UNDERSTANDING between}

THE ASSOCIATION OF BC

PROFESSIONAL FORESTERS

and

THE CANADIAN INSTITUTE OF FORESTRY (NATIONAL OFFICE)

The following points have been agreed to by the above two parties and a long mutually agreeable relationship is desired.

1. There will be joint responsibility and participation in the British Columbia CIF "Ring Ceremony."

2. Both parties agree to work toward a "National Council" of forestry associations in Canada. Some form of umbrella organization is desirable at the national level to promote good forest management. The concept of a forest constituency representing labour, industry, associations, government and education is a good concept and should be worked toward.

3. Both parties agree to work together and contribute to the Regional Public Affairs Committees (RPAC) as established by the ABCPF in various regions of British Columbia.

4. The CIF will provide a voice in Ottawa on behalf of the $A B C P F$, when there is agreement.

5. The CIF National Office will provide office facilities for the $A B C P F$ in Ottawa when needed (i.e. telephone, photocopy. etc.). A cost-sharing arrangement will be discussed in individual cases.

6. The ABCPF will provide office facilities for the CIF in Vancouver (i.e. telephone, photocopy, etc.), and provincial co-ordination when desired. A cost-sharing arrangement will be discussed in individual cases.

7. It is agreed, where possible, joint news releases, submissions, briefs and meetings will be arranged on national topics of concern.

8. The CIF will provide space in The Forestry Chronicle on behalf of the ABCPF for articles and discussions on national matters of concern.

9. A meeting of the national umbrella council will be held at the CIF Annual Meeting in 1982 and provision will be made in the CIF program for this.

10. The ABCPF will provide a regional voice in British Columbia on behalf of the CIF when there is agreement.

G.J. Garner

CIF President

J.H. Cayford

CIF Vice-President

Place: Prince George, BC

Date: 28 Sept. 1982

\section{Coordination of CIF Activities Within Multi- Section Provinces}

The Executive Committee of the CIF has adopted a policy of encouraging cooperation, communication and coordination between ourselves and others having similar forestry goals. However, it is not enough that we work with other organizations, but we must develop better coordination mechanisms in the three provinces where there is more than one CIF Section, namely British Columbia, Ontario and Quebec. Some progress has been made in this regard over the past two years, but the EC proposes that more can and should be done. The EC also recommends that the focal point for this coordination should be the Director. The following proposals are advanced for consideration and discussion at the meetings of Directors in multi-section provinces proposed for Prince George.

(a) Annually, on the morning preceding the Board of Directors meeting, Directors from multi-section provinces will convene along with members of the Executive Committee. At each meeting a Provincial Coordinator will be elected for the ensuing year and a discussion will be held concerning improved communications and joint projects. Each year Directors in each province will be requested to develop one specific project.

(b) It is recommended that the following documents be circulated to all sections within the province.

(i) Section meeting information and notices

(ii) Section meeting minutes

(iii) Section newsletters

(iv) Section annual reports

(c) At the Annual Meetings of the Professional Foresters Associations in BC, Quebec and Ontario, provision should be made for meetings of CIF/IFC Directors or representatives.

(d) The Executive Director should be requested to promote the need for improved communications between the sections within a province and should provide up-to-date address and telephone lists for section executives within the provinces of BC, Quebec and Ontario.

It is hoped that this memorandum will stimulate the action needed to effectively coordinate CIF activities on a regional basis and that dynamic sections will evolve which are willing to tackle the many complex issues we now face.

J.H. Cayford

August 30, 1982

\section{Meeting of Ontario Section Directors September 29, 1982}

1. Jack Flowers, Northwestern Ontario Section, accepted the position as Ontario Coordinator.

2. Sections will circulate:

i. Minutes,

ii. Schedule of meetings with program,

iii. Special projects,

directly to all Ontario Section chairmen.

3. Will coordinate with OPFA and other groups.

4. Will plan a meeting of section directors (or an alternate) at 1983 OPFA meeting.

5. Will be working on a brief to the Honourable A. Pope, regarding the need for urgent reassessment of Ontario's forest resource and the measures which have recently been developed to improve it.

D.A. Dickson 


\section{Meeting of British Columbia Sections - September 25, 1982}

Present:
G. Boothroyd (Van.)
W. Dumont (Pac.)
F. Einfeldt (Cariboo)
G. Wallis (Van. IsI)
C. Hayhurst (Arrowsmith)
W. Camenzind (Pac. NW)

Representatives from Okanagan and Kootenay were not present.

The purpose of the meeting was to discuss the issue of Regional Coordinator of CIF for British Columbia.

1. It was agreed that Vancouver Section and Graham Boothroyd, Section Director, would be the BC Regional Coordinator (BCRC) for the CIF for 1982-83.

2. All sections agreed to distribute the following to each section.

a) Meeting agendas and Minutes.

b) Program outlines and meeting dates.

c) Newsletters.

d) Section Executive lists.

e) Special program details.

This material will be sent to the Section Director and Secretary on regular basis, ie. the attached list of Section representatives will be added to each section mailing list.

3. It was recommended that each section amend their Bylaws or Duty lists to include the appointment of Section Director (or other Executive member) as liaison with the BCRC.
4. The BCRC was given the authority to liase on behalf of BC sections with the ABCPF Council.

5. The BCRC will distribute a list of ABCPF Regional Public Officers Committee (RPAC) chairmen to all Section Directors. All Sections were urged to cooperate with RPAC's in their areas.

6. The BCRC will act as liaison between BC Sections and CIF Executive Committee on national issues when timing of response is critical.

7. Sections agreed to cooperate more closely on both local and provincial issues.

8. Guidelines for formalization of the BCRC were discussed. Recommendations included:

i) BCRC should be a Section Director.

ii) BCRC should not become a secretary for disemination of info but rather coordinate matters.

iii) Should be appointed at AGM.

iv) Arrange meetings of Section Reps at ABCPF annual meeting.

v) BCRC will likely advise on eventual formation of BC Regional CIF Council.

9. It was agreed that Okanagan and Kootenay Sections would be asked to ratify the foregoing and participate in the "Regional" council.

10. Subsequent to the meeting the Okanagan Rep. suggested the BCRC draft an amendment referred to in item 3 above.

BC Regional CIF Section Representatives

1982-1983

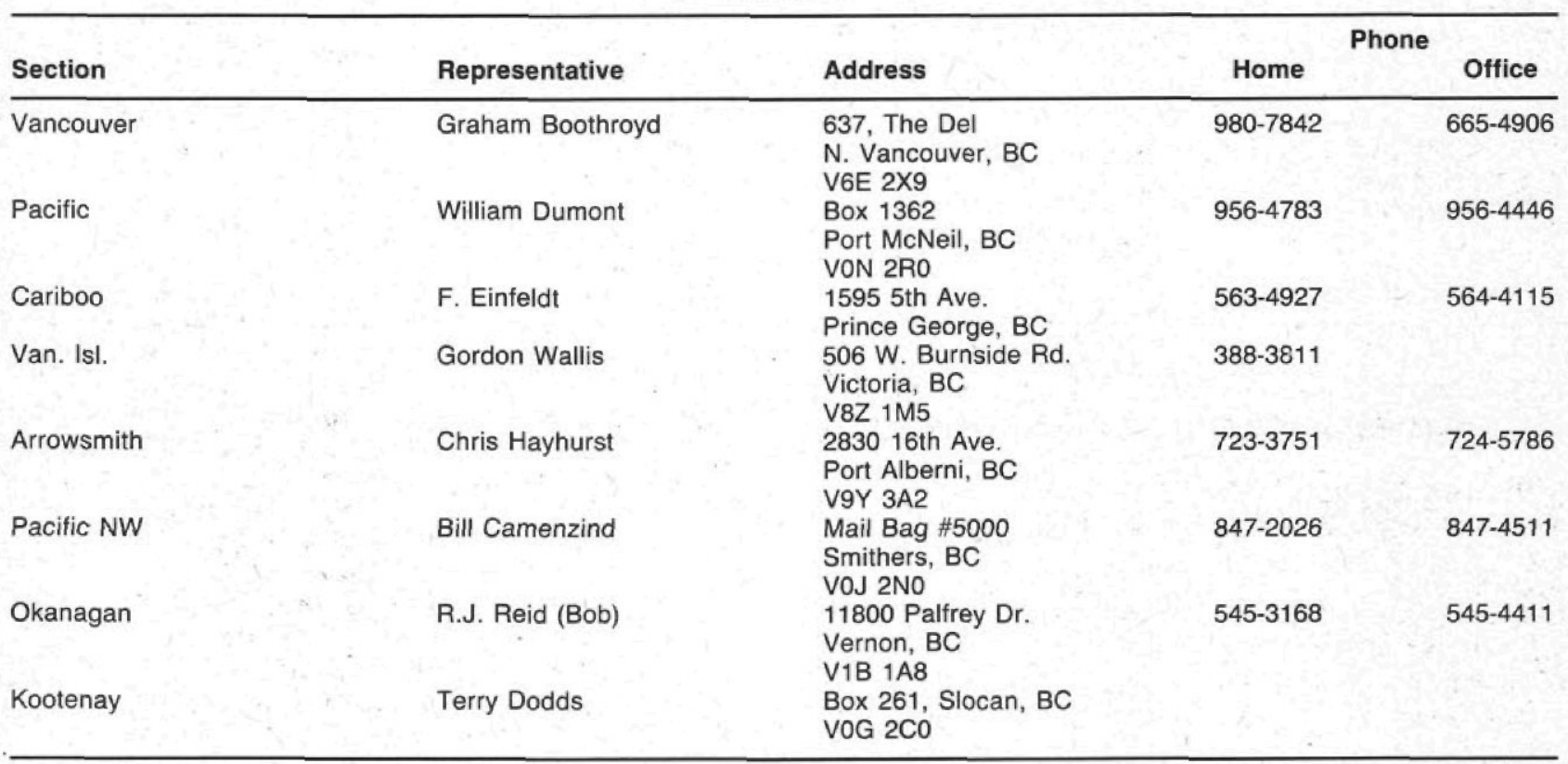

W. Dumont 